\title{
The Psychology of Invisibility: Experimentation in Low Intensity Warfare Khalfani Malik Khaldun
}

When we become too influential as prisoners with the outside and the inside, experiments are launched to alter the level of support we receive.

\section{Emotional Support Systems}

The reality of prison compels those of us within the walls to establish crucial ties with the outside. These emotional support systems are needed to help maintain the mental balance we require to stay healthy and survive. Letters and visits from loved ones serve as a validation of sorts that lends credulity to the belief that love remains intact. Knowing that there are those on the outside who will, upon request, attempt to send money for the purchase of personal survival products is quite important, so that we can take care of our needs without total dependence on the prisoncrats, who use our requirements as behavioural control mechanisms.

Outside support systems serve to assist us in resisting such forms of abuse. The officials who strive to do this are served notice, by such support, that if they bring harm to those whom outside people love and respect, there will be a response. The prisoncrats are thus less quick to violate their rights as compared to those prisoners who lack outside support.

The state has and will continue to do things in an attempt to destroy the solid emotional support systems many prisoners have. They will slander one's name, start vicious rumors, encourage reactionary prisoners to work with the officials against one, destroy incoming and outgoing mail, and a host of other repressive measures to create paranoia and feelings of abandonment.

\section{The Psychology of Invalidation}

As human beings, we all seek self-worth; the validation of our individual abilities and creativity through the words of otherpeople. This is accomplished through personal contact and communications. For those prisoners who have their physical contact restricted, being cut off from society as a whole, attention from and contact with the outside world becomes paramount. 
Prisoncrats are now using the Control Unit (or Special Handling Unit, SHU) pandemically to completely shut off what little contact a prisoner normally had. This type of penology has had and continues to wreak great damage on families and children, and supporters, as well as the prisoners, which ultimately results in a process of "psychological invalidation". When all of one's systems of support are shut off, one is vulnerable to attack and mental destruction. Isolation slowly initiates a process that serves to make one look like a liar, a con artist, a trouble-maker or a fraud. This is done to invalidate and discredit one amongst one's supporters, in the hope that those outside people will abandon you. If the invalidation is successful, the prisoncrats win, because the prisoner is blinded and struck deaf with the loss of outside support. This is psychological experimentation intended to destroy the prisoner.

\section{The Psychology of Disconnection}

Do you understand that isolation can breed insanity? If this is known to be true (as it is), then why do you think such systems of control are still in use? The answer is simple. The prisoncrats are in the business of manufacturing systemic conditions solely for the purpose of disconnecting us from having contact with the outside, because when a prisoner remains connected to the outside free world, it is like still being able to touch freedom. Losing the ability to imagine freedom can potentially kill the desire to obtain one's own freedom from prison.

Removing the contact visits and placing the prisoner on non-contact status automatically disturbs the relationship and slowly erodes the validity of the bond between family, children and friends, who are forced to visit behind a glass window. In addition to the 23 hour daily isolation of the Control Unit and the loss of contact visits, telephone contact is reduced from one hour per day to 20 minutes once every seven days. These barriers devastate relationships. People feel discouraged and ultimately lose the will to challenge or resist this disconnection from society. Being able to hear the voice of the woman you love on the other end of a phone, when she is unable to visit, helps maintain the relationship. All restrictions that serve to disconnect people from those they love are meant to cause harm. 


\section{The Psychology of Mail Tampering}

Mail tampering is a major problem inside Control Units. We are all the victims of the prying eyes and hands of the mailroom personnel (disgruntled employees with the disagreeable assignment of sorting it). Apparently their dissatisfaction with this undesirable assignment manifests itself in the sick satisfaction they receive from reading the personal and emotional expressions of pain, love and anger that is exchanged in letters to and from our loved ones. They are aware of who are our loved ones, friends, supporters and associates. Knowing this gives the enemy an edge and they use it to full advantage. Let it be understood - contact with loved ones helps to keep us sane and alive. It helps a man who is connected to his woman to feel complete and whole. Being in prison, one already realizes what has been taken from him. So, meeting and reconnecting, or maintaining a relationship with a woman one loves is like taking back what they have taken from us.

When one becomes a target of these prisoncrats, they come from all angles, probing for the points at which they can most hurt one. The mail is always a likely target because it is your emotional connection to those you love and care about. In addition, the legal mail is your connection to your case and your legal representative and your possible freedom. It is their intention to destroy these life lines whenever possible.

In the past 90 days, prisoncrats in these confines (Wabash Valley Correctional Facility) have launched a campaign to render me "invisible" by attacking both my personal and legal mail. Systematically, the Control Unit personnel, whose job it is to sort mail, have put my personal mail in the bags of other prisoners. This is happening because, on this unit, we have stepped up to challenge them and expose them for illicit actions.

We write to gain solid support on the outside, and when they read letters agreeing to help us, they may withhold this mail, or give it to another prisoner whom they believe will help them carry out their agenda. These inmates are snitches or SHU collaborators who have for years worked with staff to discredit prisoners who are speaking against human rights violations. These inmates are encouraged to write to your families, women, and supporters with the intent to disconnect them from us. These actions create very dangerous situations, creating the desire to punish these men for working with the administration prisoncrats to do us harm. These games are being played throughout the state of Indiana, targeting prisoners who have taken conscious steps to resist being casualties of this low intensity 
psychological warfare. This is a warfare that is rarely seen or recognized by the everyday citizen.

\section{The Psychology of Character Assassination}

Prison environments are a microcosm of the communities from which many prisoners come. The prisoncrats have a diabolical history of targeting certain prisoners they dislike and endeavouring to disconnect them from their influence over other prisoners. Character assassination is a way of life on the inside. The rumour highway has been known to destroy some of the best men who have attained leadership positions. Why or how?

So many psychological instabilities run rampant throughout the system. Rumours find a home in times of idleness. People need things to gossip about; it helps to pass the time. These rumours and this gossip become weapons for the prisoncrats. To insert a rumour into the mill of the general population that a certain prisoner is a snitch or an agent collaborator is equivalent to killing that man and what he stands for, without any actual physical assault. It has become a means by which prisoncrats isolate and destroy prison leaders. Such slander creates disharmony, distrust, paranoia, suspicion and even disloyalty.

This is how character assassination is used to invalidate prisoners whom they feel are disruptive to the social order they desire to exist in these types of units. Occasionally, rumours are proven by credible review and documentation. Mostly, however, they are mere interpretations of what somebody feels or assumes, or what a certain prisoncrat has passed on verbally to a prisoner. These actions have caused many prisoners to be abused unjustly, to the benefit of the system.

\section{Tricks of the Prisoncrat Trade}

- Undermining all emotional support.

- Physical removal of prisoners from those whom they respect, in order to break or seriously weaken close emotional ties.

- Creating the belief amongst prisoners that they have been abandoned and are totally isolated from the social order.

- Using techniques of character invalidation such as humiliation; revilement; shouting to induce feelings of guilt, fear and suggestibility; and sleep deprivation.

- Systematic withholding of mail. 
- Segregation of natural leaders.

- Placing individuals whose willpower has been severely weakened or eroded into environments that destroy their self-esteem, confidence and self-worth.

- Spying on prisoners and reporting back private materials of prisoners.

- Tricking men into written statements which are then shown to others.

- Exploitation of informants and inmate opportunists.

- Convincing prisoners that they can trust no one but the prisoncrats.

- Treating those willing to collaborate with leniency.

- Punishing those who show uncooperative attitudes.

- Providing social and emotional support systems that reinforce new attitudes.

- Rewarding submission and subservience to the attitudes encompassing the brainwashing objectives with a lifting of pressure and acceptance as a human being.*

\begin{abstract}
About the Author
Brother Khalfani Malik Khaldun (\#874304) (aka Leonard McQuay) was born and raised in Gary, Indiana. As a teenager he became involved with local gangs, and during his senior year in high school was involved in a shootout. At the age of 17, he was sentenced to 25 years. Over the next seven years he completed a GED, tutored, and generally established himself in the prison culture. He was preparing for release (1997) and a future when he was charged with the stabbing death of a prison guard, January 31, 1995. This charge was not proceeded with until his release on parole, July 27, 2000, when he was "gated". An "all white jury" convicted him and he was sentenced to 60 years. He has spent the last seven years in the SHU, where he has continued to struggle to expose the oppressive conditions of the control unit. His writing has been published in numerous community and activist journals, and on a number of websites.

He may be contacted at: Wabash Valley Correctional Facility, B-302, P.O. Box 1111, Carlisle, IN 47838, U.S.A.
\end{abstract}

* For a further elaboration of these disciplinary techniques, see Morgan, Lisa and Little Rock Reed, editors (1993) the Journal of Prisoners on Prison, Volume 4:2. 